\title{
Disability, mortality, and incidence of cancer among Geneva painters and electricians: a historical prospective study
}

\author{
E GUBERAN, ${ }^{1}$ M USEL, ${ }^{1}$ L RAYMOND,${ }^{2}$ R TISSOT,${ }^{3}$ P M SWEETNAM ${ }^{4}$ \\ From the Geneva Medical Inspectorate of Factories, ${ }^{1}$ Geneva Cancer Registry, ${ }^{2}$ Department of Social and \\ Preventive Medicine of the University of Geneva, Department of Biological Research and Clinical \\ Psychopharmacology, ${ }^{3}$ Psychiatric Institutions of the University of Geneva, CH-1207 Geneva, Switzerland, and \\ MRC Epidemiology Unit (South Wales), ${ }^{4}$ Cardiff, UK
}

ABSTRACT The 1916 painters and the 1948 electricians who resided in the Canton of Geneva at the time of the 1970 census were identified and followed up to 1984. During the study period 121 disability pensions were awarded to painters and 59 to electricians. Age standardised incidence of disability per 1000 man-years at risk was higher among painters than among electricians for all neuropsychiatric causes $(1 \cdot 23 / 1000$ and $0 \cdot 68 / 1000$, respectively) and for all other causes (5.50/1000 and 3.41/1000, respectively). No case of presenile dementia was diagnosed among painters. There was inadequate evidence to indicate that the higher risk of neuropsychiatric disability for painters might have been due to their occupational exposure to organic solvents. A possible toxic effect of these substances on the central nervous system was confounded with alcoholism which was associated with disability from neuropsychiatric disease in 12 of 20 painters and in only one of 10 electricians. Mortality ang incidence of cancer were assessed among both cohorts and compared with the expected figures. calculated from Geneva rates. Among painters there was a significant increase in overall mortalif $(O=254, E=218 \cdot 5)$, in mortality from all cancers $(O=96, E=75 \cdot 4)$, and in incidence from all cancers $(\mathrm{O}=159, \mathrm{E}=132 \cdot 0)$. For the specific cancer sites, there was a significant excess risk for lung cancer (mortality: $O=40, E=23.0$ ), which was possibly related to occupational exposure to asbestos and to zinc chromate, although cigarette smoking was not controlled. The significant excesses of biliary tract cancer and of bladder cancer were in accordance with previous observations among painters from other countries. There was also a significant increase in incidence from testicular cancer $(\mathrm{O}=5, \mathrm{E}=1 \cdot 6)$, which has not been reported before. For causes of death other than cancer, the excesses for alcoholism $(O=5, E=0 \cdot 8)$, for liver cirrhosis $(O=14, E=8 \cdot 8)$, for motor vehicle accidents $(\mathrm{O}=12, \mathrm{E}=5.9)$, and for cerebrovascular disease when allowing for ten years of latency $(\mathrm{O}=8, \mathrm{E}=4.0)$, were consistent with a probable increased risk of alcohol abuse. Among electricians overall mortality was similar to that expected $(O=137, E=139 \cdot 0)$. No significant excess risk was found for all cancers or for any specific cancer site. Because of the small number of expected deaths the statistical power was low for the assessment of a possible risk for leukaemia or for brain tumour.

During the past ten years or so, several Scandinavian authors have reported non-specific neuropsychiatric disorders, attributed to a chronic toxic encephalopathy, among workers with long term exposure to solvents. In more severe cases "presenile dementia" and occasionally cerebral atrophy have been des-

Accepted 18 January 1988 cribed.' Ths syndrome has been recognised as an $N$ occupational disease in Nordic countries where it has $\mathrm{N}$ been a frequent cause of premature retirement, $\sigma$ especially in Denmark. ${ }^{2}$ It is known as the "painters' syndrome" because it was first described among painters. $^{3}$

The initial purpose of the present study was to examine the incidence of neuropsychiatric disability 
among Geneva painters by comparison with that among Geneva electricians. Later on, the study was extended to the analysis of mortality and incidence of cancer among both groups.

\section{Population and methods}

The base cohorts were constituted by all painters $(n=1993)$ and all electricians $(n=1992)$ resident in the Canton of Geneva at the time of the 1970 census. The men were identified in the census files and traced through various registers according to methods previously described. ${ }^{4}$

From the base cohorts, 77 painters and 44 electricians were eliminated for the following reasons: (a) foreigners who did not appear in the records of the Population Office of Geneva (32 painters, 15 electricians); (b) men who died or emigrated before the start of the follow up (1 January 1971) (six painters, five electricians); (c) occupations wrongly classified as painters (six men) or electricians (two men); and (d) duplicate and other errors ( 33 painters, 22 electricians).

The remaining 1916 painters and 1948 electricians constituted the study cohorts. According to the classification of occupations used in the 1970 census, painters were distributed into 1338 building painters (wallpaper hangers included), 196 plasterer painters, 195 car painters, 68 other spray painters, and 119 sign painters and other painters. Electricians were distributed into 1833 "electricians" and 115 car electricians; the former category included: $(a)$ electricity installers and repairmen, (b) telephone installers, and (c) linemen and cable jointers. It did not include electrical and electronics fitters and assemblers, or radio and television repairmen. About a third of the painters and half the electricians were certified professionals. The number of self employed was 258 painters $(13.5 \%)$ and 68 electricians (3.5\%).

The workers were followed up from 1 January 1971 to 31 December 1984, or to their death, or to the date at which their trace was lost. Of 763 foreign painters, $230(30 \%)$ were lost to follow up when they left Switzerland and similarly $174(27 \%)$ of the 649 foreign electricians. Thirteen of the 1153 Swiss painters and 31 of the 1299 Swiss electricians were known to have emigrated. Among them no painter and only one electrician were lost to follow up; the others were traced through Swiss Consulates, registers in their "Commune of origin," population offices of neighbouring cities of France, or family members remaining in Geneva.

\section{DISABILITY STUDY}

In Switzerland a $100 \%$ disability pension is awarded to men under age 65 who have lost, due to disease or accident, at least two thirds of their ability for a gainful employment in an equilibrated labour market. When the loss of ability is between half and two thirds, a $50 \%$ pension is awarded. The disability pension is paid whether the disease or accident is work related or not.

The workers of both cohorts who received a $50 \%$ or $100 \%$ disability pension during the study period (1 January 1971 to 31 December 1984) were identified in the files of the Geneva section of the Swiss "Assurance Invalidité." Men below age $\mathbf{3 0}$ were excluded because disability due to the "painters' syndrome" was not reported and seems unlikely among the younger age groups. Official coding of the cause of disability by the insurance board (only the main cause was coded) was used to classify the pensions in the selected categories of disability. Subsidiary diagnoses were extracted from the insurance records which contained medical forms completed by the treating physician(s) in all cases, and often reports of medical experts, especially from the outpatients or inpatients departments of the Geneva university hospital. In addition, hospital records of the 10 painters and the six electricians who had been admitted to the Geneva University psychiatric clinic were examined.

Only the date of the awarding of the pension and the official code number of disability were available for five painters and four electricians whose insurance records were not kept. For two other painters who both died from hepatic cirrhosis and one electrician who died from oesophageal cancer, it could not be ascertained if they had received a disability pension during a few months before death and these three cases were eliminated.

The cause specific disability incidence per 1000 manyears for 1971 to 1984 , among painters and among electricians, was standardised for age using as standard population the two cohorts combined. The differences were tested using the method described by Berry. ${ }^{5}$

For convenience in the presentation of the results, the code number of the Swiss classification of disabilities was recoded by us in table 1 according to the 8th revision of the International Classification of Diseases (ICD).

No information was available about cause specific disability rates among the whole population. For comparison with the painters, occupations such as bricklayer, which was used as referent in Scandinavian studies, ${ }^{1}$ were considered. The proportion of foreign workers resident in the Canton of Geneva at the $\mathbf{1 9 7 0}$ census was however much higher among bricklayers $(86 \%)$ than among painters $(41 \%)$, or electricians $(34 \%)$, or among all Geneva industrial workers outside the construction industry $(36 \%)$. The great majority of the electricians included in the cohort were working in housing and in industrial and commercial 
Table 1 Number of pensions (1971-84) by official cause of disability and age standardised incidence $\dagger$ per 1000 man-years among painters and electricians. (Number of cases with the mention of alcoholism as a contributing cause of disability in parentheses)

\begin{tabular}{|c|c|c|c|c|}
\hline \multirow[b]{2}{*}{$\begin{array}{l}\text { Cause of disability } \\
\text { (ICD code, 8th revision) }\end{array}$} & \multicolumn{2}{|l|}{ Painters } & \multicolumn{2}{|c|}{ Electricians } \\
\hline & $\begin{array}{l}\text { No of } \\
\text { pensions }\end{array}$ & $\begin{array}{l}\text { Age adjusted } \\
\text { incidence }\end{array}$ & $\begin{array}{l}\text { No of } \\
\text { pensions }\end{array}$ & $\begin{array}{l}\text { Age adjusted } \\
\text { incidence }\end{array}$ \\
\hline $\begin{array}{l}\text { Psychosis }(290,292-299) \\
\text { Alcoholism }(291,303) \\
\text { Neurosis, personality disorders }(300-302,304-307) \\
\text { Nervous system }(320-358) \\
\text { Circulatory system }(390-458) \\
\text { Respiratory system }(460-519) \\
\text { Musculoskeletal system }(710-738) \\
\text { Neoplasm (140-239) } \\
\text { Accident }(800-949) \\
\text { Other causes } \\
\text { All causes }\end{array}$ & $\begin{array}{r}1(1) \\
4 \\
11(7) \\
4(0) \\
31(2) \\
9(2) \\
26(1) \\
11(2) \\
15(1) \\
9(3) \\
121(19)\end{array}$ & $\begin{array}{l}0 \cdot 07 \\
0 \cdot 23 \\
0 \cdot 68 \\
0 \cdot 25 \\
1 \cdot 62^{*} \\
0.49 \\
1.42 \\
0 \cdot 58 \\
0 \cdot 89 \\
0 \cdot 50 \\
6 \cdot 72^{* *}\end{array}$ & $\begin{array}{r}1(0) \\
0 \\
6(1) \\
3(0) \\
10(1) \\
4(2) \\
11(0) \\
7(1) \\
12(0) \\
5(2) \\
59(7)\end{array}$ & $\begin{array}{l}0.06 \\
0.00 \\
0.39 \\
0.23 \\
0.77 \\
0.33 \\
0.75 \\
0.46 \\
0.78 \\
0.32 \\
4.09\end{array}$ \\
\hline
\end{tabular}

$* \mathrm{p}<0.05 ; * \mathrm{p}<0.01$.

+ Standard population $=$ both cohorts combined.

establishments, similar to the painters. The socioeconomic levels of the two occupational groups were similar, as indicated by the minimum hourly wages in 1984: 17.1 Swiss francs for painters and 16.9 for electricians. ${ }^{6}$ Thus electricians were considered to be the best available comparison group of sufficient size.

\section{MORTALITY AND CANCER INCIDENCE STUDY}

The Swiss "Office fédéral de la statistique" supplied us with official death certificate codings for all men who died within the country. During the whole study period the ICD 8th revision was in force in Switzerland. Among the 10 deaths abroad (five painters and five electricians), the cause was obtained in four cases from a copy of the death certificates, in four cases from information from the wife, and from notices in Geneva newspapers for two men who died in the neighbouring region of France (one ski accident and one sudden cardiac death). The incident cancers were collected by the Geneva Cancer Registry.

Expected deaths and expected cases of cancer were calculated from regional rates as described previously. ${ }^{7}$ Expected deaths were based on 23289 man-years of observation of painters and on 24807 man-years of observation of electricians. The figures were a little less (22 398 and 23387 , respectively) for the incidence of cancer study because the periods of residence outside the Canton of Geneva should be excluded, due to the lack of a national cancer registry.

For the analysis of mortality from alcoholism we combined deaths from alcoholic psychosis (ICD-8: 291), alcoholism (303), and accidental poisoning by alcohol (E 860). The latter was included because in Switzerland most of the deaths allocated to this code are due to acute alcoholic intoxication.

The one sided significance of the excesses of observed deaths and of incident cancers was tested by the usual method based on the Poisson distribution.

\section{Results}

\section{DISA BILITY}

Table 2 shows age specific incidence of disability per 1000 man-years and overall crude incidence for the whole study period 1971-84. The overall crude incidence of disability was twice as high among painters as among electricians. The age distribution of $\overrightarrow{0}$ man-years, however, shows that the painters were ono average older than the electricians. Age specific doability was always higher by about $50 \%$ among the painters except for the youngest age group (30-34). $\frac{\bar{a}}{5}$

There was higher age standardised incidence among painters than among electricians for all the selected categories of disability, although the difference was $\cong$ only significant for circulatory disease and for all $\vec{\circ}$ causes (table 1).

For the four categories of neuropsychiatric disease, there were 20 pensions granted to painters and 10 to electricians. Age standardised incidence per 1000 manyears was respectively 1.23 and 0.68 (difference not $\stackrel{\Phi}{3}$ significant), which gave a risk of disability among painters of 1.8 relative to the risk among electricians.

Among the 20 painters, alcoholism was the main cause of disability in four cases (one Korsakoff's $₹$ syndrome) and a contributing cause in eight. Among을 the 10 electricians, alcoholism was a contributing cause for one case only.

There was no main or subsidiary diagnosis of presenile dementia or cerebral atrophy among pain- $-r$ ters. One electrician was granted a pension because $N$ cerebral atrophy was diagnosed on the CT scan. This స్ట was attributed to multiple cerebrovascular infarctions.

Considering all non-neuropsychiatric diagnoses together, the age standardised incidence of disability pensions was $5 \cdot 50 / 1000$ man-years among painters@ and 3.41/1000 among electricians (relative risk 1.6). The difference was significant at the $1 \%$ level. 
Table 2 Number of disability pensions (1971-84) and incidence per 1000 man-years at risk among painters and electricians

\begin{tabular}{|c|c|c|c|c|c|c|}
\hline \multirow[b]{2}{*}{ Age } & \multicolumn{3}{|l|}{ Painters } & \multicolumn{3}{|c|}{ Electricians } \\
\hline & $\begin{array}{l}\text { No of } \\
\text { pensions }\end{array}$ & Man-years & $\begin{array}{l}\text { Incidence/ } \\
1000 \mathrm{~m}-\mathrm{y}\end{array}$ & $\begin{array}{l}\text { No of } \\
\text { pensions }\end{array}$ & Man-years & $\begin{array}{l}\text { Incidence/ } \\
1000 \mathrm{~m}-\mathrm{y}\end{array}$ \\
\hline $\begin{array}{l}30-34 \\
35-39 \\
40-44 \\
45-49 \\
50-54 \\
55-59 \\
60-64\end{array}$ & $\begin{array}{r}4 \\
8 \\
13 \\
10 \\
16 \\
39 \\
31\end{array}$ & $\begin{array}{l}2735 \\
2899 \\
2605 \\
2208 \\
1975 \\
1881 \\
1831\end{array}$ & $\begin{array}{r}1.46 \\
2.76 \\
4.99 \\
4.53 \\
8.10 \\
20.73 \\
16.93\end{array}$ & $\begin{array}{r}6 \\
3 \\
8 \\
6 \\
12 \\
13 \\
11\end{array}$ & $\begin{array}{r}3746 \\
3394 \\
2826 \\
2244 \\
1725 \\
1278 \\
992\end{array}$ & $\begin{array}{r}1.60 \\
0.88 \\
2.83 \\
2.67 \\
6.96 \\
10.17 \\
11.09\end{array}$ \\
\hline All ages & 121 & 16134 & $7 \cdot 50$ & 59 & 16204 & 3.64 \\
\hline
\end{tabular}

Among the selected categories of disability, incidence was significantly higher among painters for circulatory disease (table 1). More detailed analyses indicated that there were 18 pensions (incidence: 0.96 / $1000)$ among painters and eight $(0.63 / 1000)$ among electricians for heart disease, eight $(0.41 / 1000)$ and none, respectively, for cerebrovascular disease, and five $(0 \cdot 25 / 1000)$ and two $(0 \cdot 14 / 1000)$, respectively, for other vascular diseases.

Clinical data of the eight cases of cerebrovascular disease among painters indicated that there was a typical feature of stroke syndrome with a more or less severe hemiplegia in six men, a Wallenberg's syndrome in one, and a spontaneous haematoma of the left occipital lobe in the remaining one.

\section{MORTALITY AND INCIDENCE OF CANCER}

Among painters, mortality and incidence were significantly higher than expected from Geneva rates for gallbladder cancer, lung cancer, and all malignant neoplasms (table 3). Incidence but not mortality from bladder cancer and from testicular cancer were also significantly increased. There was no significant excess for all malignant neoplasms or for any specific site among electricians (table 4).

Overall mortality and mortality from selected causes other than malignant neoplasm may be seen in table 5. There was a significant excess of observed deaths among painters for all causes, motor vehicle accident, and alcoholism. No significant excess of mortality was observed among electricians.

Table 6 gives the observed and expected deaths among painters during the first 10 years (1971-80), and the 11 th to 14 th years $(1981-4)$, since the start of follow up. The SMRs from the leading causes of deaths increased with longer follow up. This was possibly due to the process of selection and survival described as the "healthy worker effect." The mortality excess during the last period was highly significant for all causes, malignant neoplasm, lung

Table 3 Cancer mortality and incidence among painters (1971-84)

\begin{tabular}{|c|c|c|c|c|c|c|c|c|}
\hline \multirow{2}{*}{$\begin{array}{l}\text { Site (ICD code, } \\
\text { 8th revision) }\end{array}$} & \multicolumn{4}{|c|}{ Deaths } & \multicolumn{4}{|c|}{ Cases of cancer } \\
\hline & Obs & $\operatorname{Exp}$ & $S M R$ & $90 \% \mathrm{CI}$ & Obs & $\operatorname{Exp}$ & $S I R$ & $90 \% \mathrm{CI}$ \\
\hline $\begin{array}{l}\text { All malignant neoplasms }(140-209) \\
\text { Buccal cavity, pharynx }(140-149) \\
\text { Oesophagus (150) } \\
\text { Stomach (151) } \\
\text { Intestine, rectum (152-154) } \\
\text { Liver (155) } \\
\text { Gallbladder (156) } \\
\text { Pancreas (157) } \\
\text { Larynx (161) } \\
\text { Lung (162) } \\
\text { Skin (172-173) } \\
\text { Prostate (185) } \\
\text { Testis (186) } \\
\text { Bladder (188) } \\
\text { Kidney (189) } \\
\text { Brain (191) } \\
\text { Hodgkin's disease (201) } \\
\text { Non-Hodgkin's lymphoma }(200,202) \\
\text { Leukaemia (204-207) } \\
\text { Others and unknown }\end{array}$ & $\begin{array}{r}96 \\
7 \\
2 \\
1 \\
6 \\
5 \\
3 \\
1 \\
2 \\
40 \\
0 \\
5 \\
2 \\
7 \\
3 \\
1 \\
0 \\
1 \\
1 \\
9\end{array}$ & $\begin{array}{r}75 \cdot 4 \\
3 \cdot 8 \\
2 \cdot 9 \\
4 \cdot 1 \\
7 \cdot 6 \\
3 \cdot 2 \\
0 \cdot 7 \\
3 \cdot 5 \\
1 \cdot 9 \\
23 \cdot 0 \\
1 \cdot 5 \\
6 \cdot 0 \\
0 \cdot 4 \\
3 \cdot 4 \\
2 \cdot 0 \\
1 \cdot 9 \\
0 \cdot 9 \\
1 \cdot 4 \\
2 \cdot 0 \\
5 \cdot 2\end{array}$ & $\begin{array}{c}127^{* *} \\
184 \\
69 \\
24 \\
79 \\
156 \\
429^{*} \\
29 \\
105 \\
174^{* * *} \\
83 \\
500 \\
206 \\
150 \\
52 \\
71 \\
50 \\
173\end{array}$ & $\begin{array}{c}107-151 \\
86-346 \\
12-217 \\
1-116 \\
34-156 \\
55-292 \\
117-1108 \\
1-136 \\
19-331 \\
131-226 \\
0-200 \\
33-175 \\
89-1574 \\
97-387 \\
41-388 \\
3-250 \\
0-333 \\
4-339 \\
23-237 \\
90-302\end{array}$ & $\begin{array}{r}159 \\
13 \\
2 \\
5 \\
15 \\
5 \\
3 \\
1 \\
5 \\
40 \\
21 \\
13 \\
5 \\
13 \\
4 \\
3 \\
0 \\
2 \\
1 \\
8\end{array}$ & $\begin{array}{r}132.0 \\
8.7 \\
3.0 \\
7 \cdot 5 \\
14.9 \\
3.6 \\
0.8 \\
3.0 \\
4 \cdot 4 \\
27 \cdot 3 \\
18 \cdot 3 \\
12 \cdot 3 \\
1.6 \\
7.6 \\
3.4 \\
2.1 \\
1.0 \\
2.5 \\
2.3 \\
7 \cdot 3\end{array}$ & $\begin{array}{l}120^{* *} \\
149 \\
67 \\
67 \\
101 \\
139 \\
375^{*} \\
33 \\
114 \\
147^{* *} \\
115 \\
106 \\
313^{*} \\
171^{*} \\
118 \\
143 \\
80 \\
43 \\
110\end{array}$ & $\begin{array}{r}105-137 \\
88-238 \\
12-210 \\
26-140 \\
62-155 \\
55-292 \\
102-969 \\
2-158 \\
45-239 \\
111-191 \\
77-165 \\
63-168 \\
123-657 \\
101-272 \\
40-269 \\
39-369 \\
0-300 \\
14-252 \\
2-206 \\
55-198\end{array}$ \\
\hline
\end{tabular}

${ }^{*} p<0.05 ; *{ }^{* *}<0.01 ; * * * p<0.001$. 
Table 4 Cancer mortality and incidence among electricians (1971-84)

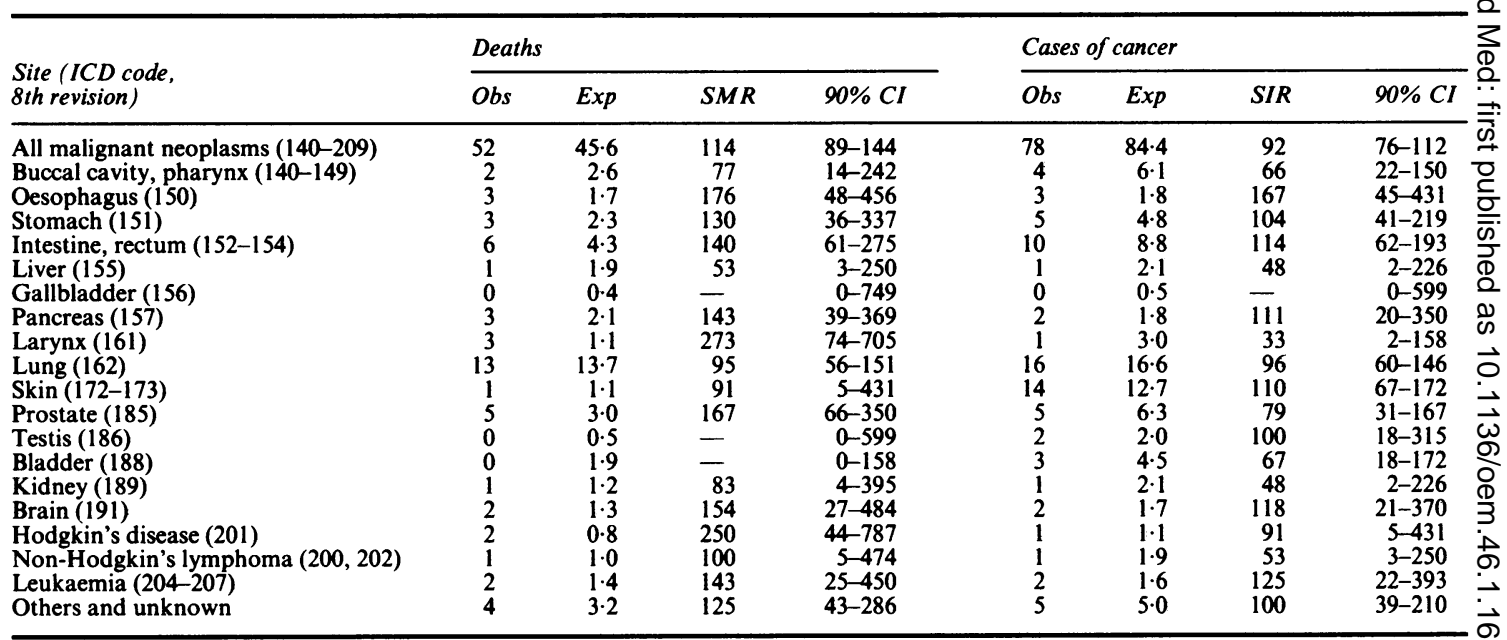

cancer, and circulatory disease. Analysis of the various categories of circulatory disease showed a significant excess for heart disease $(O=32, E=20.8, p<0.01)$, which was due to "other forms of heart disease" $(\mathrm{O}=17, \mathrm{E}=7.8, \mathrm{p}<0.01)$ rather than to ischaemic heart disease $(\mathrm{O}=15, \mathrm{E}=13.0)$. There was also an excess of borderline significance for cerebrovascular disease $(O=8, E=4 \cdot 0, p=0 \cdot 05)$.

By contrast, there was no increase in SMR with longer follow up among electricians. Within the last period (1981-84) the SMRs were 102 for all causes, 87 for malignant neoplasm, and 92 for circulatory disease.

No death certificate mentioned cerebral atrophy or presenile dementia as the underlying or a contributing cause in painters or in electricians.

The underlying cause of the five painters' deaths from alcoholism was delirium tremens for one, chronic chronic alcoholism for three, and acute alcoholic $\stackrel{\circ}{\stackrel{5}{~}}$ intoxication for one.

Among the subgroup of building painters $(70 \%$ of all painters), excesses were similar to those observed for the whole cohort, as expected. The increase in mortality from bladder cancer $(O=6, E=2 \cdot 4, \overrightarrow{0}$ $\mathrm{p}<0.05)$ and from liver cirrhosis $(\mathrm{O}=12, \mathrm{E}=6.2,8$ $\mathrm{p}<0.05$ ) however, reached the conventional level statistical significance, contrary to the increase amon all painters.

\section{Discussion}

THE PAINTERS' SYNDROME

All painters living in Geneva canton at the time of the 1970 census were followed up for 14 years. Scrutiny of the causes of the 254 deaths and 121 disability pensions showed no case of presenile dementia. Never-

Table 5 Mortality from all causes and from non-malignant causes among painters and electricians (1971-84)

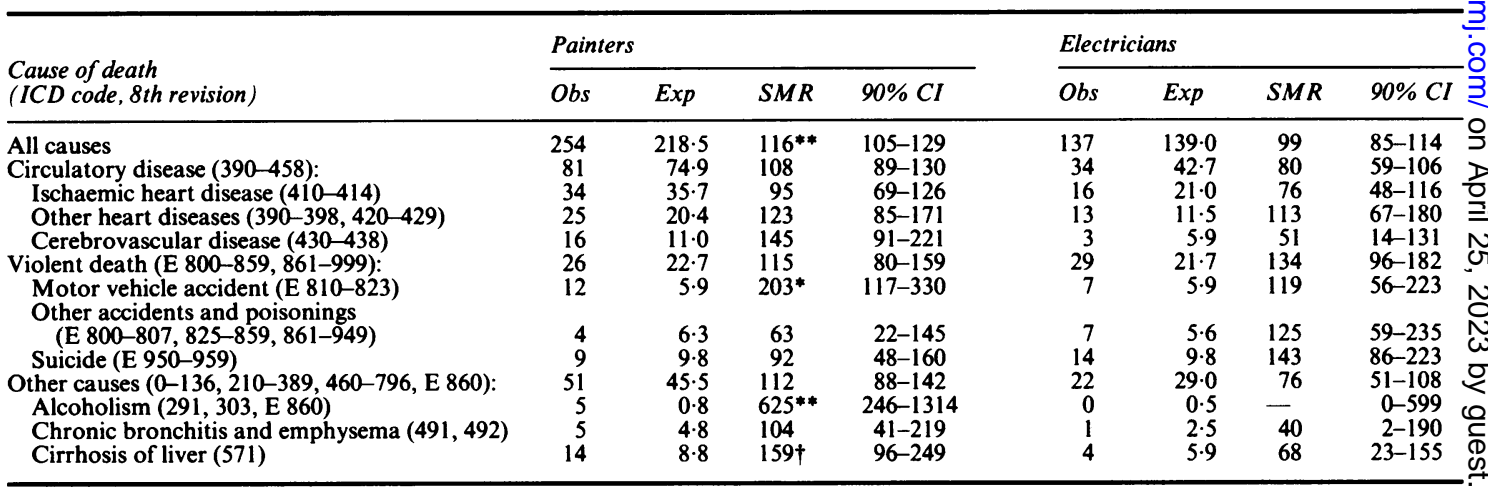

${ }^{*} \mathrm{p}<0.05 ; * * \mathrm{p}<0.01$

$+\mathrm{p}=0.06$ 
Table 6 Mortality among painters from the leading categories of deaths and from lung cancer for two periods of follow up

\begin{tabular}{|c|c|c|c|c|c|c|c|c|}
\hline \multirow{2}{*}{$\begin{array}{l}\text { Cause of death } \\
\text { (ICD code, } 8 \text { th revision) }\end{array}$} & \multicolumn{4}{|c|}{$1971-80$} & \multicolumn{4}{|c|}{$1981-4$} \\
\hline & Obs & $\operatorname{Exp}$ & $S M R$ & $90 \% C I$ & Obs & $\operatorname{Exp}$ & $S M R$ & $90 \% C I$ \\
\hline $\begin{array}{l}\text { All causes } \\
\text { Malignant neoplasm }(140-209) \text { : } \\
\text { Lung cancer }(162) \\
\text { Circulatory disease }(390-458) \\
\text { Violent death }(\mathrm{E} 800-859,861-999) \\
\text { Other causes }(0-136,210-389,460-796, \text { E 860) }\end{array}$ & $\begin{array}{r}145 \\
55 \\
23 \\
38 \\
18 \\
34\end{array}$ & $\begin{array}{r}143 \cdot 5 \\
48 \cdot 4 \\
15 \cdot 1 \\
47 \cdot 3 \\
16 \cdot 8 \\
31 \cdot 0\end{array}$ & $\begin{array}{l}101 \\
114 \\
152^{*} \\
80^{-} \\
107 \\
110\end{array}$ & $\begin{array}{r}88-116 \\
90-142 \\
104-216 \\
60-105 \\
69-159 \\
81-146\end{array}$ & $\begin{array}{r}109 \\
41 \\
17 \\
43 \\
8 \\
17\end{array}$ & $\begin{array}{r}75 \cdot 0 \\
27 \cdot 0 \\
7.9 \\
27 \cdot 6 \\
5 \cdot 9 \\
14 \cdot 5\end{array}$ & $\begin{array}{l}145^{* * *} \\
152^{* *} \\
215^{* *} \\
156^{* *} \\
136 \\
117\end{array}$ & $\begin{array}{r}123-170 \\
115-197 \\
137-323 \\
119-202 \\
67-245 \\
75-176\end{array}$ \\
\hline
\end{tabular}

${ }^{*} \mathrm{p}<0.05 ;{ }^{* *} \mathrm{p}<0.01 ; * * * \mathrm{p}<0.001$.

theless, a variety of less severe non-specific disorders of the central nervous system have been attributed to the chronic effects of solvents. ${ }^{8}$ This occupational hazard could conceivably account for the higher incidence of disability observed in this study among painters than among electricians for the four categories of neuropsychiatric disease taken together. Solvent exposure, however, was confounded with alcoholism, which was associated with neuropsychiatric disease in 12 of 20 painters and only one of 10 electricians.

It should be pointed out that the insurance board can reduce a pension by $50 \%$ in cases of alcoholism. We believe that Geneva physicians have taken this into account and have mentioned this diagnosis only when there was no doubt that their patient had a long history of alcohol related medical and social problems.

An increased risk for alcohol abuse among painters is supported by the mortality data which showed a significant excess of mortality from alcoholism and an excess of mortality from liver cirrhosis of borderline significance, although the latter excess was significant among the subgroup of building painters.

In conclusion, there was inadequate evidence to support a solvent related painters' syndrome from our 1971-84 analysis of disability among Geneva painters, despite the fact that hundreds of their Scandinavian fellow workers received compensation because of this syndrome during the same period. ${ }^{2}$ There is no clear explanation for this discrepancy.

Mortality data were searched for suggestions. Observed mortality from all causes and from the leading causes of death among electricians was similar to that expected from Geneva rates. It is therefore unlikely that the relatively high incidence of disability among painters could be due to a better than average state of health of the occupational group selected for comparison.

In our previous cohort studies in Geneva there was no significant mortality excess from the main causes of death among hairdressers ${ }^{7}$ or among chemical workers who stayed at least one year,' similar to the findings among electricians. Contrary to the concordant mortality experience of these three occupational cohorts, painters showed an increase in mortality which was particularly pronounced (allowing for ten years of latency) for all causes, all malignant neoplasms, lung cancer, and circulatory disease.

Thus mortality and disability data are in agreement suggesting that Geneva painters are an unhealthy occupational group at higher risk from various diseases. It might be assumed that this is accountable for by a set of life style and occupational factors, some of which will be discussed below.

MORTALITY AND INCIDENCE OF CANCER AMONG PAINTERS

\section{Lung cancer}

The present study supports previous findings of an association between the occupation as a painter and lung cancer shown in two cohort studies of Swedish ${ }^{10} 11$ and United States painters 1213 and in "occupational disease surveillance studies" based on vital records ${ }^{1417}$ and cancer registry data. ${ }^{1819}$ Adjusting for cigarette smoking in two of these studies did not change the association..$^{1319}$

In common with painters from other countries, ${ }^{20}$ Geneva painters had in previous decades direct exposure to asbestos containing materials such as sealant and other compounds and indirect exposure to asbestos materials used by other trades in the building industry.

On the other hand, metal protective primers containing zinc chromate pigments were widely used by Geneva painters until recently. Zinc chromate has been shown to induce lung cancer in animals ${ }^{21}$ and has been assumed to be the main factor in the excess of lung cancer reported among chrome pigment makers ${ }^{21}$ and spray painters. ${ }^{22}$ Our inquiries indicated that Geneva building painters were exposed to zinc chromate during spray painting of non-ferrous metals and during removal of old primers often by sanding, before the application of a new coat of paint. But spray painters of machine tools, who constituted almost exclusively the subgroup of 68 "other spray painters," were certainly more regularly exposed to zinc chromate containing primers. Our mortality results suggest a high risk of lung cancer among these men 
$(\mathrm{O}=4, \mathrm{E}=1.0, \mathrm{p}<0.05)$, although based on a small number of deaths.

In conclusion, the highly significant excess of lung cancer among Geneva painters was possibly related to occupational exposure to two lung carcinogens: asbestos and zinc chromate. Unfortunately, we have no data on the duration and level of exposure or on smoking habits. This precludes any tentative estimate of the proportion of the excess of lung cancer which may be ascribed to occupation.

\section{Other cancers}

The significantly increased risk for cancer of the biliary tract among Geneva painters was based on one cancer of the gallbladder and two cancers of the extrahepatic bile ducts. This observation is in agreement with the increased incidence from biliary cancer found among Swedish painters. ${ }^{1023}$

There were five cases of testicular cancer among Geneva painters (two seminomas, two teratomas, one lymphoma) when 1.6 were expected. No previous report has mentioned an association of testicular cancer with the occupation of painter and a chance excess should be considered.

Our finding of an excess of bladder cancer among painters supports the results of two case-control studies on bladder cancer, ${ }^{24}{ }^{25}$ of a proportionate mortality study among artistic painters, ${ }^{26}$ and of one of the above quoted occupational disease surveillance studies. ${ }^{18}$ Smoking or occupational exposure to unknown bladder carcinogen(s), or both, might be postulated to explain the excess among Geneva painters.

For alcohol related cancers (buccal cavity, pharynx, oesophagus, liver, and larynx) there was no significant excess risk. An increase in mortality and in incidence was nevertheless observed for cancer of the buccal cavity and pharynx $($ SMR $=184$, SIR $=149)$ and for liver cancer $(\operatorname{SMR}=156, \operatorname{SIR}=139)$ but as for cancers of the oesophagus and larynx the chances of detecting a significant excess were limited by the small numbers of expected deaths and cases of cancer.

\section{Causes of death other than cancer}

We have already discussed the probably higher than average alcohol consumption among Geneva painters and the related mortality from alcoholism and from hepatic cirrhosis. This risk factor is consistent with the significant excess of observed deaths from motor vehicle accident, and with the mortality excess of borderline significance from cerebrovascular disease when allowing for ten years of latency. As to this latter excess there is strong evidence of an association of heavy drinking with stroke $\mathrm{e}^{27-30}$ and with hypertension, ${ }^{31}$ a well recognised risk factor for stroke. ${ }^{32}$

It should be pointed out that the increased risk for cerebrovascular disease is supported by the disability $\overline{\bar{z}}$ study which showed, as we have seen, eight cases among painters and none among electricians.

Mortality was significantly increased after a latency $?$ of ten years, for "other forms of heart disease." This category of deaths includes various heart disorders, especially cardiac insufficiency, a diagnosis often made by Swiss physicians, for ill defined causes of deaths. It cannot be ruled out that this mortality excess had some $\overrightarrow{\widetilde{D}}$ relation with the "alcoholic cardiomyopathy" des- 응 cribed among chronic alcohol abusers. ${ }^{334}$ This latter ${ }^{30}$ diagnosis, however, could not be found on the relevant $\vec{O}$ death certificates.

\section{MORTALITY AND INCIDENCE OF CANCER AMONG} ELECTRICIANS

Several reports have suggested an increased risk of leukaemia for various categories of electrical workers, $\stackrel{\vec{\phi}}{\vec{\phi}}$ although evidence is still controversial (reviews ${ }^{3536}$ ). $\overrightarrow{\vec{\sigma}}$ Excess mortality or incidence were also reported for $\bar{\sigma}$ lung cancer, ${ }^{3738}$ mesothelioma, ${ }^{3940}$ brain tumours, ${ }^{41}$ 을 malignant melanoma of the skin, ${ }^{4243}$ and cancer of the pharynx. ${ }^{38}$

In the present study there was no significant excess of cancer for any specific site. Observed and expected incidence of leukaemia $(\mathrm{O}=2, \mathrm{E}=1 \cdot 6)$, brain can- $\vec{\theta}$ cer $(\mathrm{O}=2, \mathrm{E}=1 \cdot 7)$, malignant melanoma $(\mathrm{O}=1$, $\mathrm{E}=2 \cdot 1)$, and cancer of the pharynx $(\mathrm{O}=8$, $E=3 \cdot 1)$, however, were based on small numbet There was no excess of lung cancer although in the pasi Geneva electricians have needed to pierce and sa. asbestos plates that were set on the walls behind electrical boards for thermal insulation.

We thank Professor $H$ Savolainen (Lausanne), Professor M A Cooke (Birmingham), Dr F Paccaud (Lausanne), and Dr A Morabia (Baltimore) for their critical review of the manuscript. We are also grateful $\delta$ to Mrs H El May-Meziane, Mrs N Gros, and Mrs A Favre for work on the incidence data. We have benefited from the technical help of Mr T Boysan, Mr P Cadby, Mrs G Farine, Mrs J Gorgé-Dubois, §̊ Mr N A Nguyen, Mr H Steffen, and Mrs A Tyack.

Requests for reprints to: Dr E Gubéran, Service du médecin du travail, 23 rue Ferdinand Hodler, CH-1207 Geneva, Switzerland.

\section{References}

1 Grasso P, Sharratt M, Davies DM, Irvine D. Neurophysiologica and psychological disorders and occupational exposure to organic solvents. Food Chem Toxicol 1984;22:819-52.

2 Cohr KH. Danish experience with white spirit. In: Cherry N, Waldron HA, eds. The neuropsychological effects of solvent exposure. London: Colt Foundation, 1983:51-62. 
3 Axelson O, Hane M, Hogstedt C. A case-referent study on neuropsychiatric disorders among workers exposed to solvents. Scand J Work Environ Health 1976;2:14-20.

4 Gubéran E, Usel M. Unusual mortality pattern among short term workers in the perfumery industry in Geneva. $\mathrm{Br} \mathrm{J}$ Ind Med 1987;44:595-601.

5 Berry G. The analysis of mortality by the subject-years method. Biometrics 1983;39:173-84.

6 Office fédéral de l'industrie, des arts et métiers et du travail. Les taux de salaires pratiqués en octobre 1984 dans les grandes villes en vertu de conventions collectives de travail ou de réglementations publiques. La Vie Economique 1984;57:825-9.

7 Gubéran E, Raymond L, Sweetnam PM. Increased risk for male bladder cancer among a cohort of male and female hairdressers from Geneva. Int J Epidemiol 1985; 14:549-54.

8 Waldron HA. Solvents and the brain. Br J Ind Med 1986;43:73-4.

9 Gubéran E, Raymond L. Mortality and cancer incidence in the perfumery and flavour industry of Geneva. $\mathrm{Br} \mathrm{J}$ Ind Med 1985;42:240-5.

10 Englund A. Cancer incidence among painters and some allied trades. J Toxicol Environ Health 1980;16:1267-73.

11 Engholm G, Englund A. Cancer incidence and mortality among Swedish painters. In: Englund A, Ringen K, Mehlman M, eds. Advances in modern environmental toxicology. Vol II. Occupational health hazards of solvents. Princeton: Princeton Scientific Publishers, 1982:173-85.

12 Matanoski GM, Stockwell HG, Diamond EL, et al. A cohort mortality study of painters and allied tradesmen. Scand J Work Environ Health 1986;12:16-21.

13 Stockwell HG, Matanoski GM. A case-control study of lung cancer in painters. J Occup Med 1985;27:125-6.

14 Menck HR, Henderson BE. Occupational differences in rates of lung cancer. J Occup Med 1976;18:797-801.

15 Logan WPD. Cancer mortality by occupation and social class 18511971. OPCS. Studies on medical and population subjects. (No 44.) London: HMSO, 1982:205, 246.

16 Milne KL, Sandler DP, Everson RB, Brown SM. Lung cancer and occupation in Alameda county: a death certificate case-control study. Am J Ind Med 1983;4:565-75.

17 Dubrow R, Wegman DH. Cancer and occupation in Massachusetts: a death certificate study. Am J Ind Med 1984;6:207-30.

18 Decoufle P, Stanislawczyk K, Houten L, Bross IDJ, Viadana E. A retrospective survey of cancer in relation to occupation. Cincinnati: National Institute for Occupational Safety and Health, 1977. (DHEW (NIOSH) publication No 77-178.)

19 Williams RR, Stegens NL, Goldsmith IR. Associations of cancer site and type with occupation and industry from the third national cancer survey interview. $J N C I$ 1977;59:1147-85.

20 Nicholson WJ, Perkel G, Selikoff IJ. Occupational exposure to asbestos: population at risk and projected mortality - 1980 2030. Am J Ind Med 1982;3:259-311.

21 Levy LS, Martin PA, Bidstrup PL. Investigation of the potential carcinogenicity of a range of chromium containing materials on rat lung. Br J Ind Med 1986;43:243-56.

22 Dalager NA, Mason TJ, Fraumeni JF, Hoover R, Payne WW. Cancer mortality among workers exposed to zinc chromate paints. J Occup Med 1980;22:25-9.
23 Malker HSR, McLaughlin JK, Malker BK, et al. Biliary tract cancer and occupation in Sweden. Br J Ind Med 1986;43:257-62.

24 Jensen OM, Wahrendorf J, Knudsen JB, Sorensen BL. The Copenhagen case-referent study on bladder cancer. Scand $J$ Work Environ Health 1987;13:129-34.

25 Claude J, Kunze E, Frentzel-Beyme R, Paczkowski K, Schneider $\mathrm{J}$, Schubert $\mathrm{H}$. Life-style and occupational risk factors in cancer of the lower urinary tract. Am J Epidemiol 1986;124:578-89.

26 Miller BA, Silverman DT, Hoover RN, Blair A. Cancer risk among artistic painters. Am J Ind Med 1986;9:281-7.

27 Gill JS, Zezulka AV, Shipley MJ, Gill SK, Beevers DG. Stroke and alcohol consumption. $N$ Engl J Med 1986;315:1041-6.

28 Donahue RP, Abbott RD, Reed DM, Yano K. Alcohol and hemorrhagic stroke: the Honolulu heart program. JAMA 1986;255:2311-4.

29 Kozararevic D, McGee D, Vojvodic N, et al. Frequency of alcohol consumption and morbidity and mortality: the Yugoslavia cardiovascular disease study. Lancet 1980;i:613-6.

30 Blackwelder WC, Yano K, Rhoads GG, Kagan A, Gordon T, Palesch Y. Alcohol and mortality: the Honolulu heart study. Am J Med 1980;68:164-9.

31 Saunders JB. Alcohol: an important cause of hypertension. $\mathrm{Br}$ Med J 1987;294:1045-6.

32 Kannel WB, Wolf PA, Verter J, McNamara PM. Epidemiologic assessment of the role of blood pressure in stroke: the Framingham study. JAMA 1970;214:301-10.

33 Brigden W, Robinson J. Alcoholic heart disease. Br Med J 1964;ii:1283-9.

34 Rubin JI, Rubin E. Myocardial toxicity of alcohols, aldehydes, and glycols, including alcoholic cardiomyopathy. In: Van Stee EW, ed. Cardiovascular toxicology. New York: Raven Press, 1982:353-63.

35 Savitz DA, Calle EE. Leukemia and occupational exposure to electromagnetic fields: review of epidemiologic surveys. JOccup Med 1987;29:47-51.

36 Sheikh K. Exposure to electromagnetic fields and the risk of leukemia. Arch Environ Health 1986;41:56-63.

37 Damber LA, Larsson LG. Occupation and male lung cancer: a case-control study in northern Sweden. Br J Ind Med 1987;44:446-53.

38 Vagerö D, Olin R. Incidence of cancer in the electronics industry: using the new Swedish cancer environment registry as a screening instrument. Br J Ind Med 1983;40:188-92.

39 Coggon D, Pannett B, Osmond C, Acheson ED. A survey of cancer and occupation in young and middle aged men. $I$. Cancers of the respiratory tract. Br J Ind Med 1986;43:332-8.

40 Malker HSR, McLaughlin JK, Malker BK, et al. Occupational risks for pleural mesothelioma in Sweden, 1961-79. JNCI 1985;74:61-6.

41 Lin RS, Dischinger PC, Conde J, Farrell KP. Occupational exposure to electromagnetic fields and the occurrence of brain tumors. J Occup Med 1985;27:413-9.

42 Vagerö D, Ahlbom A, Olin R, Sahlsten S. Cancer morbidity among workers in the telecommunications industry. $\mathrm{Br} \mathrm{J}$ Ind Med 1985;42:191-5.

43 Olin R, Vagerö D, Ahlbom A. Mortality experience of electrical engineers. Br J Ind Med 1985;42:211-2. 